\title{
Dentin phosphophoryn promotes cellular migration of human dental pulp cells
}

Yoshiyuki Yasuda, DDS, PhD, Masanobu Izumikawa, DDS, PhD,

Kuniaki Okamoto, DDS, PhD, ${ }^{1}$ Takayuki Tsukuba, DDS, PhD,${ }^{1}$ Takashi Saito, DDS, PhD

Division of Clinical Cariology and Endodontology, Department of Oral Rehabilitation, School

of Dentistry, Health Sciences University of Hokkaido, Hokkaido, 061-0293, Japan

${ }^{1}$ Division of Oral Molecular Pharmacology, Department of Developmental and Reconstructive

Medicine, Nagasaki University Graduate School of Biomedical Sciences, Nagasaki, 852-8588,

Japan

Address requests for reprints to Dr. Yoshiyuki Yasuda, Division of Clinical Cariology and

Endodontology, Department of Oral Rehabilitation, School of Dentistry, Health Sciences

University of Hokkaido, 1757 Kanazawa, Ishikari-Tobetsu, Hokkaido, 061-0293 Japan. TEL:

+81-133-23-2841, FAX: +81-133-23-1423, E-mail address: yasuda@hoku-iryo-u.ac.jp. 


\section{Acknowledgements}

This work was supported by Grant-in-Aid for Scientific Research (C) 18659536, and Grant-in-Aid

for Young Scientists (B) 18791407 from the Japan Society for the Promotion of Science, and by a

Grant from the Research Center, Health Sciences University of Hokkaido. 


\section{Abstract}

Dentin phosphophoryn (DPP) is a dentin sialophosphoprotein (DSPP) gene product that has an RGD motif and repeat sequences of aspartic acid and phosphorylated serine. To date, the function of DPP in the early stage of reparative dentin formation still remains unclear. The objective of this study was to evaluate the effects of DPP on pulp cell migration and proliferation. DPP promoted cell migration in a concentration-dependent manner, thus increasing it by about 3 -fold at $1000 \mathrm{ng} / \mathrm{ml}$ compared to the control, but it had no effect on cell proliferation. Dephosphorylated DPP also promoted cell migration, similarly to DPP. However, cell migration was significantly suppressed by the addition of $\alpha \mathrm{v} \beta 3$ integrin antibody to the medium. Furthermore, porcine DPP-derived RGD peptide, but not its mutant RAD peptide, significantly promoted cell migration. These results indicate that the RGD motif of DPP plays an important role in the migration of human dental pulp cells.

Key words: Phosphophoryn; dentin sialophosphoprotein; migration; RGD motif; dental pulp cells; reparative dentin 


\section{Introduction}

Reparative dentin formation on the exposed pulp surface is essential for healing after direct pulp capping (1-3). Pulp capping agents must have an activity of hard-tissue-formation as well as good biocompatibility and margin-sealing property. Calcium hydroxide has been used as a pulp-capping agent, but an inflammatory reaction of pulp tissue and uneven hard tissue formation have been observed $(4,5)$. Recently, the use of mineral trioxide aggregate (MTA) in direct pulp capping has been reported, but a variety of histological responses were still noted (6,

7). Furthermore, the data from long-term clinical results are not yet available.

Dentin phosphophoryn (DPP) is a dentin sialophosphoprotein (DSPP) gene product and a highly phosphorylated protein that accounts for $50 \%$ of non-collagenous dentinal proteins $(8$, 9). DSPP is mainly expressed in odontoblasts and it is known to be a marker of the differentiation of pulp cells into odontoblasts (10-14). DPP has the RGD motif at position 26 from the N-terminal and repeat sequences of aspartic acid and serine as its characteristic domains (15). Aspartic acid and serine account for at least $75 \%$ of all amino acid sequences, and $85-90 \%$ of the serine residues are phosphorylated (15). Porcine DPP consists of 550 amino 
acids, while human DPP comprises 839 amino acids. The characteristic motif is almost identical. We have previously reported that DPP covalently cross-linked to type I collagen induces the mineralization of the collagen in calcium phosphate solutions and plays an important role in calcification of dentin $(16,17)$. Recently, DPP has been reported to induce the differentiation of human mesenchymal stem cells into osteoblasts as its RGD motif binds with $\alpha v \beta 3$ integrin on the cell surface (18). Reparative dentin formation is considered to be achieved as the undifferentiated mesenchymal stem cells in the pulp tissue undergo the processes of migration, proliferation, differentiation into odontoblasts, and calcification (19). However, little has been reported concerning the role of DPP in the initial process of reparative dentin formation. This study was carried out to clarify the involvement of DPP in pulp cell migration and proliferation. 


\section{Materials and Methods}

\section{Cells and Cell-culture Conditions}

Human dental pulp cells were obtained from a healthy third molar of 19 years old male which

were extracted during orthodontic treatment. The protocol for these experiments was reviewed and approved by the Health Sciences University of Hokkaido Research Ethics Committee, and informed consent was obtained from all tissue donors. The pulp tissues were separated from the crown and rinsed once in PBS before being digested with $2 \mathrm{mg} / \mathrm{ml}$ collagenase (GIBCO, Grand Island, NY) at $37^{\circ} \mathrm{C}$ for $30 \mathrm{~min}$. The resultant suspension was then centrifuged to collect the released cells. These cells were subsequently cultured in Dulbecco's Modified Eagle Medium (DMEM, Sigma, St. Louis, MI) supplemented with 10\% fetal bovine serum (FBS, Sigma), $10,000 \mathrm{U} / \mathrm{ml}$ penicillin (GIBCO), and $10 \mathrm{mg} / \mathrm{ml}$ streptomycin $(\mathrm{GIBCO})$ at $37^{\circ} \mathrm{C}$ in a humidified atmosphere of $5 \% \mathrm{CO}_{2}$.

\section{Purification of Porcine DPP}

The DPP was prepared from molar teeth extracted from porcine jaws obtained from a local abattoir, as described previously (16). Briefly, the porcine dentin was powdered (400-700 $\mu \mathrm{m})$ 
under liquid nitrogen. The powdered dentin was decalcified at $4{ }^{\circ} \mathrm{C}$ with $0.5 \mathrm{M}$ EDTA and 0.05

$\mathrm{M}$ Tris- $\mathrm{HCl}, \mathrm{pH} 7.4$, including protease inhibitors (100 mM 6-aminohexanoic acid, $5 \mathrm{mM}$ benzamidine- $\mathrm{HCl}$, and $1 \mathrm{mM}$ phenylmethylsulfonyl fluoride, Sigma). The extract was dialyzed against distilled water and lyophilized. DPP was then purified using the calcium precipitation method followed by DEAE-cellulose column chromatography (Amersham Biosciences, Piscataway, NJ). After performing alkaline hydrolysis, the purified DPP underwent amino acid and phosphate analyses as described previously (17). Phosphate analyses were based on a highly colored complex of phosphomolybdate and malachite green (20).

The fragment peptide of porcine DPP-derived RGD peptide (DPP-RGD, SEGDNNHSSRGDTSYNSDES) and its mutant RAD peptide (DPP-RAD, SEGDNNHSSRADTSYNSDES) were synthesized by Invitrogen (Carlsbad, CA).

\section{Preparation of Collagen-coated Inserts}

Bovine dermal collagen solution (Sigma) was prepared according to the manufacturer's instructions. Briefly, $8 \mathrm{ml}$ of chilled collagen solution was mixed with $1 \mathrm{ml}$ of $10 \mathrm{x}$ PBS on ice. The combination was blended with $1 \mathrm{ml}$ of $0.1 \mathrm{M} \mathrm{NaOH}$ and the $\mathrm{pH}$ was adjusted to 7.2-7.6. 
The collagen gel was dispensed on the membranes of the inserts at $15 \mu \mathrm{g} / 50 \mu 1 /$ insert and then incubated at $37^{\circ} \mathrm{C}$ overnight to dryness. The inserts were rinsed with sterile water to remove any salts.

\section{Cell Migration Assay}

The migration of dental pulp cells was measured via a modified Boyden-chamber assay using a transwell polycarbonate membrane insert of $6.4 \mathrm{~mm}$ in diameter with an $8 \mu \mathrm{m}$ pore size. The transwell inserts were placed in the 24 -well plate and precoated with denatured collagen, as described above. The cells $\left(1 \times 10^{5} / \mathrm{ml}\right)$ were briefly pretreated in a final volume of $250 \mu \mathrm{l}$ of serum-free media (containing 0.1\% BSA) with porcine DPP $(0,100,250,1000,2500 \mathrm{ng} / \mathrm{ml})$, DPP-RGD $(5 \mu \mathrm{M})$, DPP-RAD $(5 \mu \mathrm{M})$ or fibronectin (Sigma, $1000 \mathrm{ng} / \mathrm{ml})$ in $1.5 \mathrm{ml}$ tubes and placed in the upper compartments. In some cases, the cells were first treated for 20 min with avß3-integrin antibody ( $25 \mu \mathrm{g} / \mathrm{ml}$, Santa Cruz Biotechnology Inc, Santa Cruz, CA $)$ in the tube, and then were placed immediately in the upper chamber. To induce the migration by chemoattractants, the lower chambers were filled with $750 \mu 1$ of serum-free media conditioned by the mouse NIH-3T3. The cells were incubated at $37^{\circ} \mathrm{C}$ for $24 \mathrm{~h}$. The cells that had not 
migrated through the barrier were removed with a cell scraper, and then the migrated cells were then stained with Diff-Quik (Sysmex, Kobe, Japan). The number of migrated cells in each well was counted in four random high power fields.

\section{Dephosphorylation of Purified Porcine DPP}

One milligram of porcine DPP was dephosphorylated with potato acid phosphatase (Sigma).

The porcine DPP was suspended in $10 \mathrm{mM}$ sodium acetate, $50 \mathrm{mM}$ EDTA, and $0.5 \mathrm{mU}$ of the enzyme/mg DPP was added. After digestion at $37^{\circ} \mathrm{C}$ for $48 \mathrm{~h}$, the enzyme was then removed by dialysis with distilled water. Phosphate analysis was performed after alkaline hydrolysis as described previously (20).

\section{Proliferation Assay}

The proliferation assays were performed using the Cell Counting Kit-8 (Dojindo, Kumamoto, Japan) according to the manufacturer's instructions. Briefly, human dental pulp cells were treated with $1000 \mathrm{ng} / \mathrm{ml}$ of porcine DPP or dephosphorylated DPP in 96-well culture plates for 5 days in a $100 \mu 1$ medium. WST-8 reagents were added to each well and incubated for $30 \mathrm{~min}$ at $37^{\circ} \mathrm{C}$. Absorbance readings at a wavelength of $450 \mathrm{~nm}$ and reference wavelength of $650 \mathrm{~nm}$ 
were taken using a spectrophotometer (Model 680; Bio-Rad, Hercules, CA).

\section{Statistical Analysis}

A statistical analysis was performed with the data obtained from five independent experiments. The data were expressed as the means \pm SD. The data were compared using one-way analysis of variance (ANOVA) followed by Tukey's multiple comparison test. $P$ values $<0.05$ were considered to be significant. 


\section{Results}

We evaluated the effects of DPP on the cell migration of human pulp cells to clarify its role in an early stage of reparative dentin formation. A clearly larger number of cells treated with DPP at $1000 \mathrm{ng} / \mathrm{ml}$ migrated than did the control cells (Fig. 1A). Concerning the DPP concentration-dependence of cell migration, the number of cells per microscopic field did not differ at $100 \mathrm{ng} / \mathrm{ml}$ compared to the control (Fig. 1B). However, it clearly increased at 250 $\mathrm{ng} / \mathrm{ml}$, and rose to about 3-fold at $1000 \mathrm{ng} / \mathrm{ml}$, compared to the control cells. On the other hand, DPP exerted no effect on pulp cell proliferation at the concentration of $1000 \mathrm{ng} / \mathrm{ml}$ (Fig. 1C).

Next, we studied whether the RGD motif or phosphate residues of DPP are related to its cell migration-promoting effect. DPP dephosphorylated with acidic phosphatase significantly promoted cell migration by 3 -fold compared to the controls, in a similar manner as that observed for the same concentration of phosphorylated DPP (Fig. 2A). Moreover, dephosphorylated as well as phosphorylated DPP showed no effect on cell proliferation (Fig. 2B). The pretreatment of pulp cells with $\alpha v \beta 3$ integrin antibody $(25 \mu \mathrm{g} / \mathrm{ml})$ significantly suppressed the cell migration-promoting effect of DPP nearly to the control level (Fig. 3A). 
We further investigated the interaction RGD motif with $\alpha v \beta 3$ integrin. Porcine DPP-RGD

peptide $(5 \mu \mathrm{M})$ significantly promoted cellular migration as well as did fibronectin as a positive control, but mutant DPP-RAD peptide did not (Fig. 3B). 


\section{Discussion}

The DSPP gene has been reported to be expressed in bone as well as teeth (21), but as the level of its expression is very low, it has been used as a marker of odontoblast differentiation in many reports (10-14). DSPP is processed at its central part immediately after synthesis and thereafter becomes dentin sialoprotein (DSP) at the N terminal and DPP at the C terminal (22). We previously showed that DPP covalently cross-linked to type I collagen plays a major role in dentin calcification $(16,17)$. This role is also suggested by reports that human DSPP gene mutation causes dentinogenesis imperfecta (23) and that DSPP-deficient mice exhibit a pathologic condition resembling human dentinogenesis imperfecta (24). We found in this study that DPP also promotes pulp cell migration. These results suggest that DPP performs various important functions in reparative dentin formation.

DSPP is a member of the SIBLING (Small Integrin-Binding LIgand, N-linked Glycoprotein) family, showing an RGD motif, phosphorylated parts, and glycosylated parts along with bone sialoprotein (BSP), osteopontin (OPN), and dentin matrix protein 1 (DMP1) (25). These proteins are considered to directly regulate the appearance and growth of the crystalline 
components of bone and teeth. In cancer cells, matrix metalloproteinase (MMP) is activated by binding with SIBLING proteins, and this activated MMP was reported to degrade the matrix around cells and promote cell migration (26). Recently, Karadag et al. found that BSP promotes the migration of bone marrow stem cells via this RGD motif, but that OPN or DMP1 has no such effect (27). In this study, DPP was found to promote pulp cell migration, as does BSP. Therefore, these differences in the function of the same RGD motif suggest that the conformation of the amino acid sequences before and after RGD thus plays an important role in the cell functions.

The treatment of pulp cells with DPP at $1000 \mathrm{ng} / \mathrm{ml}$ increased their migratory capacity by about 3-fold compared to the control cells. However, DPP at the same concentration had no effect on proliferation. This means that enhanced cell migration was not simply a result of an increase in the number of cells. Previous studies clarified the importance of RGD motif in cell differentiation, and the phosphate group in calcification $(11,16-18)$. To investigate which of the characteristic motifs is more important for the cell migratory function, we used dephosphorylated DPP, DPP-RGD peptide, DPP-RAD peptide and integrin antibody. While 
dephosphorylated DPP and DPP-RGD peptide promoted cell migration, DPP in which the RGD motif was blocked by pretreatment with integrin antibody and DPP-RAD peptide had no effect on cell migration. These results suggest that the RGD motif rather than the phosphate esters of DPP plays an important role in cell migration. Our results are supported by the findings of previous report, in which that integrins were shown to be expressed on the surface of dental pulp cells (28). However, further studies are needed to clarify precisely how the RGD motif of DPP controls cell migration and differentiation.

The wound-healing process of injured pulp tissue has recently been investigated, and the important roles of BMP and FGF2 in the early phase have been clarified. Kaida et al. found that the number of cells expressing BMPs gradually increased in reparative dentin formation (29). Furthermore, the induction of pulp cell differentiation and calcification by BMP-7 overexpression (30), and induction of reparative dentin formation by the control of FGF-2 release from a carrier have also been reported (31). It is also known that BMP and FGF2 strongly induce DSPP expression $(11,32)$. These findings suggested that DPP produced by cells stimulated with BMPs and FGF2 may promote cell migration, while also enhancing 
wound healing.

To summarize, DPP was shown to promote not only differentiation or calcification but also cell migration by acting on integrins on the surface of pulp cells via its RGD motif. Since DPP plays an important role in the process of reparative dentin formation, it may therefore be effective as a dental pulp capping agent. 


\section{Figure Legends}

Fig. 1 The effect of porcine dentin phosphophoryn (DPP) on the migration and proliferation

of dental pulp cells. Representative photographs of migrated cells (Original magnification $\times$ 400) (A). The concentration-dependent effect of DPP on cellular migration (B). The effect of DPP (1000 ng/ml) on cell proliferation: control cells (open circles), $1000 \mathrm{ng} / \mathrm{ml}$ DPP-treated cells (closed circles) (C). The bar represents the mean $\pm \mathrm{SD}\left(\mathrm{n}=5, * \mathrm{p}<0.05\right.$ vs control, ${ }^{* *} \mathrm{p}<$ 0.01 vs control).

Fig. 2 The effect of dephosphorylated DPP (De-DPP) on cellular migration (A) and proliferation: control cells (open circles), $1000 \mathrm{ng} / \mathrm{ml}$ De-DPP-treated cells (closed circles) (B). The bar represents the mean $\pm \operatorname{SD}(\mathrm{n}=5, * * \mathrm{p}<0.01$ vs control).

Fig. 3 Interaction of RGD motif with $\alpha v \beta 3$ integrin plays an important role in cell migration.

The effect of $\alpha v \beta 3$ integrin antibody on the cellular migration (A). The effect of porcine 
DPP-derived RGD peptide (DPP-RGD) and its mutant peptide (DPP-RAD) on the cellular migration (B). The bar represents the mean \pm SD $(n=5, * * p<0.01$ vs porcine DPP or DPP-RGD-treated cells). 


\section{References}

1. Cox CF, Subay RK, Ostro E, Suzuki S, Suzuki SH. Tunnel defects in dentin bridges: their formation following direct pulp capping. Oper Dent 1996;21:4-11.

2. Anderson AW, Sharav Y, Massler M. Reparative dentine formation and pulp morphology. Oral Surg Oral Med Oral Pathol 1968;26:837-47.

3. Heys DR, Cox CF, Heys RJ, Avery JK. Histological considerations of direct pulp capping agents. J Dent Res 1981;60:1371-9.

4. Freeman K, Ludington JR, Jr., Svec TA, Pinero GJ, Hoover J. Continuously infused calcium hydroxide: its influence on hard tissue repair. J Endod 1994;20:272-5.

5. Gordon TM, Ranly DM, Boyan BD. The effects of calcium hydroxide on bovine pulp tissue: variations in $\mathrm{pH}$ and calcium concentration. J Endod 1985;11:156-60.

6. Caicedo R, Abbott PV, Alongi DJ, Alarcon MY. Clinical, radiographic and histological analysis of the effects of mineral trioxide aggregate used in direct pulp capping and pulpotomies of primary teeth. Aust Dent J 2006;51:297-305.

7. Chacko V, Kurikose S. Human pulpal response to mineral trioxide aggregate (MTA): a 
histologic study. J Clin Pediatr Dent 2006;30:203-9.

8. Ritchie HH, Wang L. The presence of multiple rat DSP-PP transcripts. Biochim Biophys Acta 2000;1493:27-32.

9. Gu K, Chang S, Ritchie HH, Clarkson BH, Rutherford RB. Molecular cloning of a human dentin sialophosphoprotein gene. Eur J Oral Sci 2000;108:35-42.

10. Wei X, Ling J, Wu L, Liu L, Xiao Y. Expression of mineralization markers in dental pulp cells. J Endod 2007;33:703-8.

11. Saito T, Ogawa M, Hata Y, Bessho K. Acceleration effect of human recombinant bone morphogenetic protein-2 on differentiation of human pulp cells into odontoblasts. J Endod 2004;30:205-8.

12. Andelin WE, Shabahang S, Wright K, Torabinejad M. Identification of hard tissue after experimental pulp capping using dentin sialoprotein (DSP) as a marker. J Endod $2003 ; 29: 646-50$.

13. Min KS, Kim HI, Park HJ, Pi SH, Hong CU, Kim EC. Human pulp cells response to Portland cement in vitro. J Endod 2007;33:163-6. 
14. Ye L, Peng L, Tan H, Zhou X. HGF enhanced proliferation and differentiation of dental pulp cells. J Endod 2006;32:736-41.

15. George A, Bannon L, Sabsay B, et al. The carboxyl-terminal domain of phosphophoryn contains unique extended triplet amino acid repeat sequences forming ordered carboxyl-phosphate interaction ridges that may be essential in the biomineralization process. $\mathrm{J}$ Biol Chem 1996;271:32869-73.

16. Saito T, Arsenault AL, Yamauchi M, Kuboki Y, Crenshaw MA. Mineral induction by immobilized phosphoproteins. Bone 1997;21:305-11.

17. Saito T, Yamauchi M, Abiko Y, Matsuda K, Crenshaw MA. In vitro apatite induction by phosphophoryn immobilized on modified collagen fibrils. J Bone Miner Res 2000;15:1615-9.

18. Jadlowiec J, Koch H, Zhang X, Campbell PG, Seyedain M, Sfeir C. Phosphophoryn regulates the gene expression and differentiation of NIH3T3, MC3T3-E1, and human mesenchymal stem cells via the integrin/MAPK signaling pathway. $\mathrm{J}$ Biol Chem 2004;279:53323-30.

19. Smith AJ, Cassidy N, Perry H, Begue-Kirn C, Ruch JV, Lesot H. Reactionary 
dentinogenesis. Int J Dev Biol 1995;39:273-80.

20. Baykov AA, Evtushenko OA, Avaeva SM. A malachite green procedure for orthophosphate determination and its use in alkaline phosphatase-based enzyme immunoassay. Anal Biochem 1988;171:266-70.

21. Qin C, Brunn JC, Cadena E, et al. The expression of dentin sialophosphoprotein gene in bone. J Dent Res 2002;81:392-4.

22. Butler WT. Dentin matrix proteins. Eur J Oral Sci 1998;106 Suppl 1:204-10.

23. Xiao S, Yu C, Chou X, et al. Dentinogenesis imperfecta 1 with or without progressive hearing loss is associated with distinct mutations in DSPP. Nat Genet 2001;27:201-4.

24. Sreenath T, Thyagarajan T, Hall B, et al. Dentin sialophosphoprotein knockout mouse teeth display widened predentin zone and develop defective dentin mineralization similar to human dentinogenesis imperfecta type III. J Biol Chem 2003;278:24874-80.

25. Moses KD, Butler WT, Qin C. Immunohistochemical study of small integrin-binding ligand, N-linked glycoproteins in reactionary dentin of rat molars at different ages. Eur J Oral Sci 2006;114:216-22. 
26. Sung V, Stubbs JT, 3rd, Fisher L, Aaron AD, Thompson EW. Bone sialoprotein supports breast cancer cell adhesion proliferation and migration through differential usage of the alpha(v)beta3 and alpha(v)beta5 integrins. J Cell Physiol 1998;176:482-94.

27. Karadag A, Fisher LW. Bone sialoprotein enhances migration of bone marrow stromal cells through matrices by bridging MMP-2 to alpha(v)beta3-integrin. J Bone Miner Res 2006;21:1627-36.

28. Zhu Q, Safavi KE, Spangberg LS. Integrin expression in human dental pulp cells and their role in cell attachment on extracellular matrix proteins. J Endod 1998;24:641-4.

29. Kaida H, Hamachi T, Anan H, Maeda K. Wound healing process of injured pulp tissues with emdogain gel. J Endod 2008;34:26-30.

30. Lin ZM, Qin W, Zhang NH, Xiao L, Ling JQ. Adenovirus-mediated recombinant human bone morphogenetic protein-7 expression promotes differentiation of human dental pulp cells. J Endod 2007;33:930-5.

31. Kikuchi N, Kitamura C, Morotomi T, et al. Formation of dentin-like particles in dentin defects above exposed pulp by controlled release of fibroblast growth factor 2 from gelatin 
hydrogels. J Endod 2007;33:1198-202.

32. Nakao K, Itoh M, Tomita Y, Tomooka Y, Tsuji T. FGF-2 potently induces both proliferation and DSP expression in collagen type I gel cultures of adult incisor immature pulp cells.

Biochem Biophys Res Commun 2004;325:1052-9. 
Fig. 1

(A)

\section{Control}

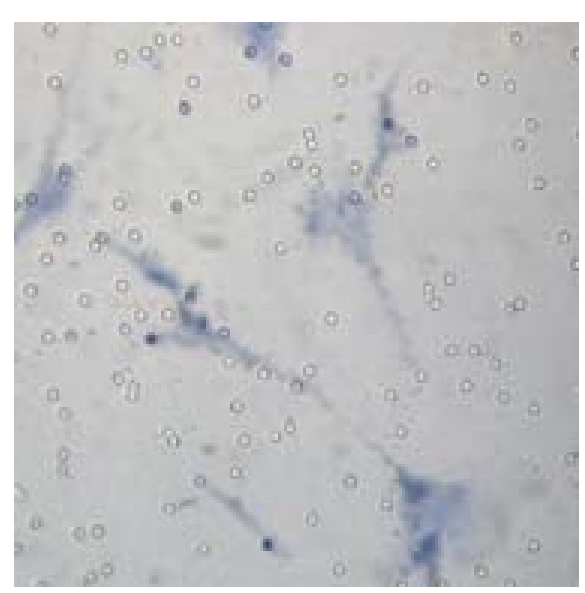

DPP $1000 \mathrm{ng} / \mathrm{ml}$

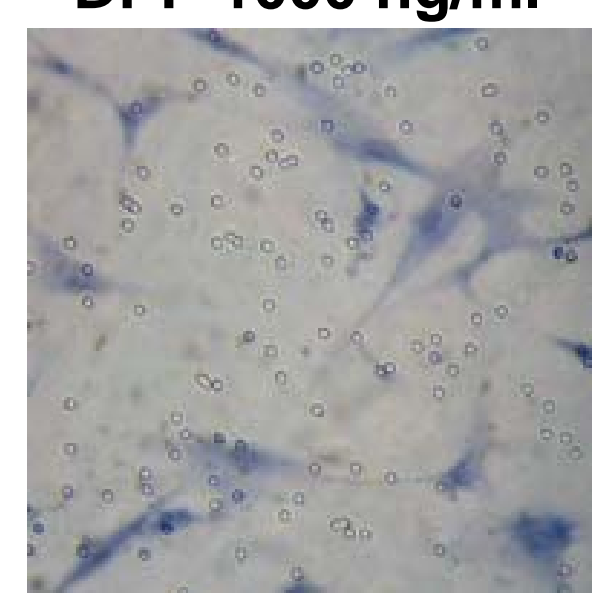

(B)

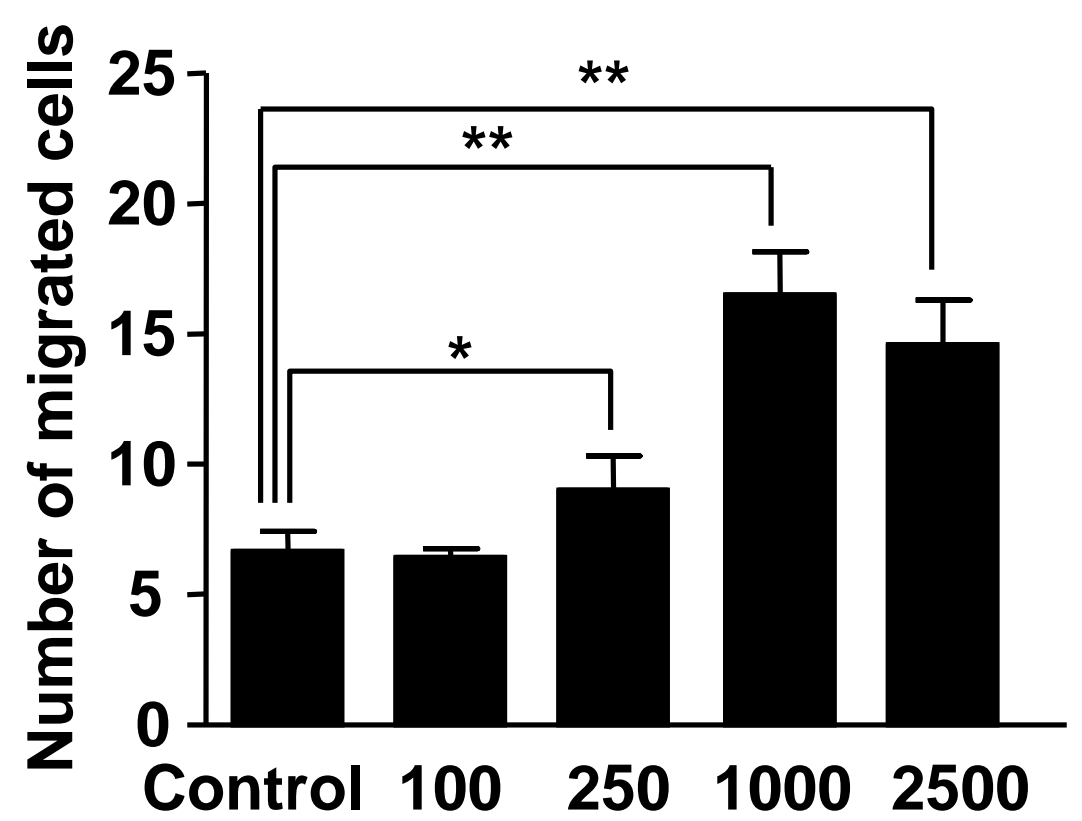

DPP (ng/ml)

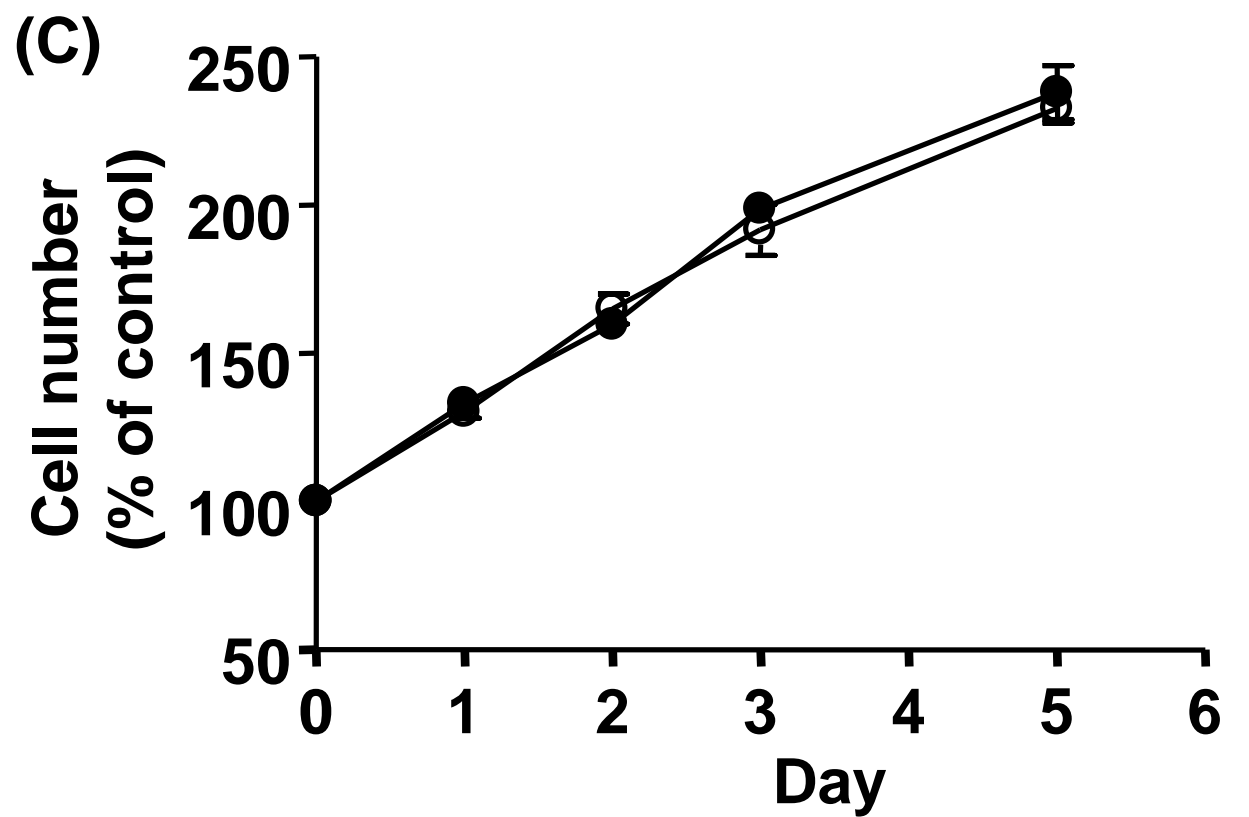


Fig. 2

(A)

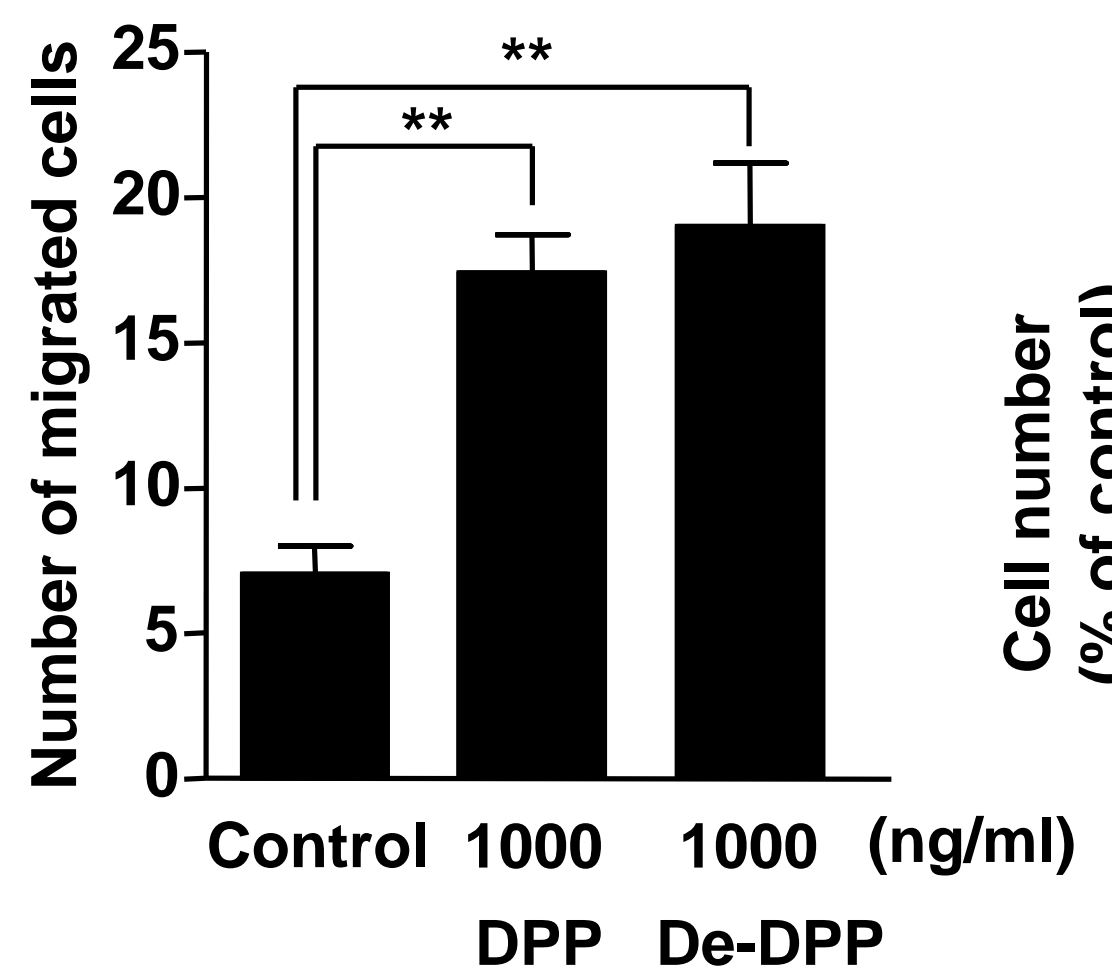

(B)

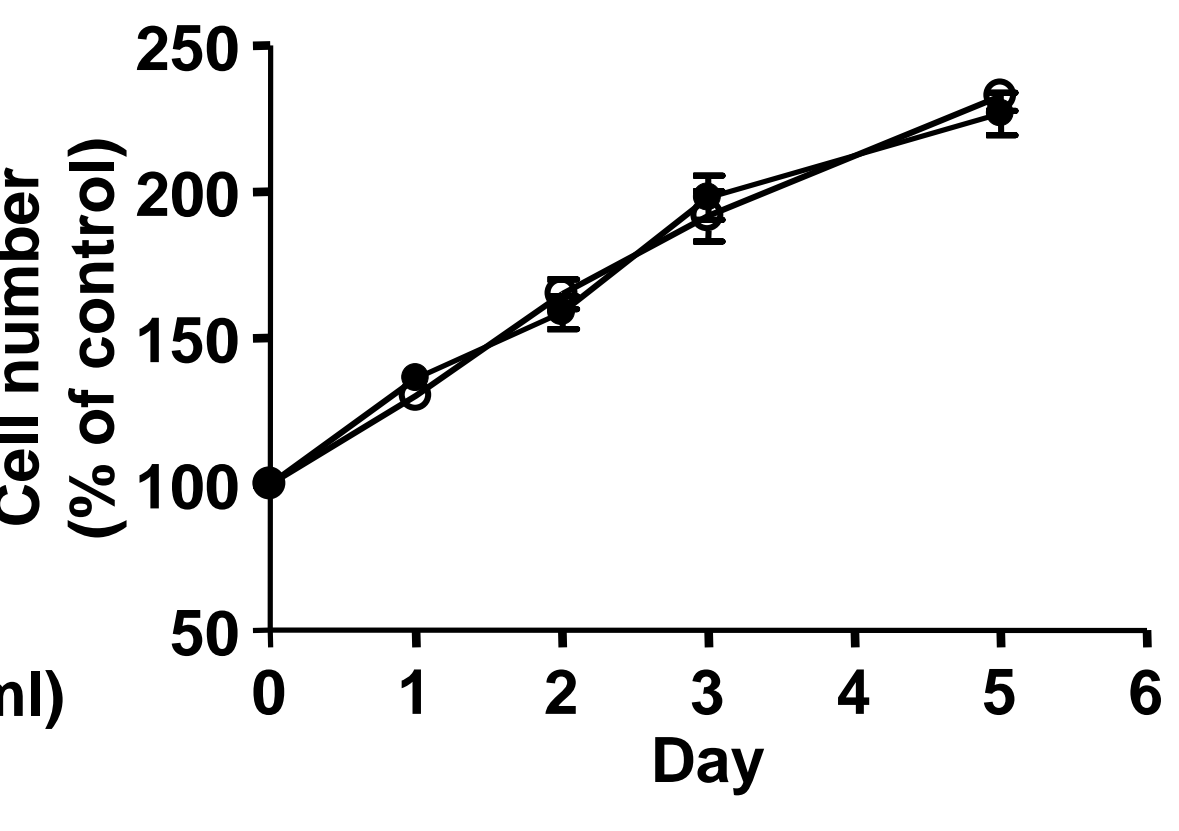


Fig. 3

(A)

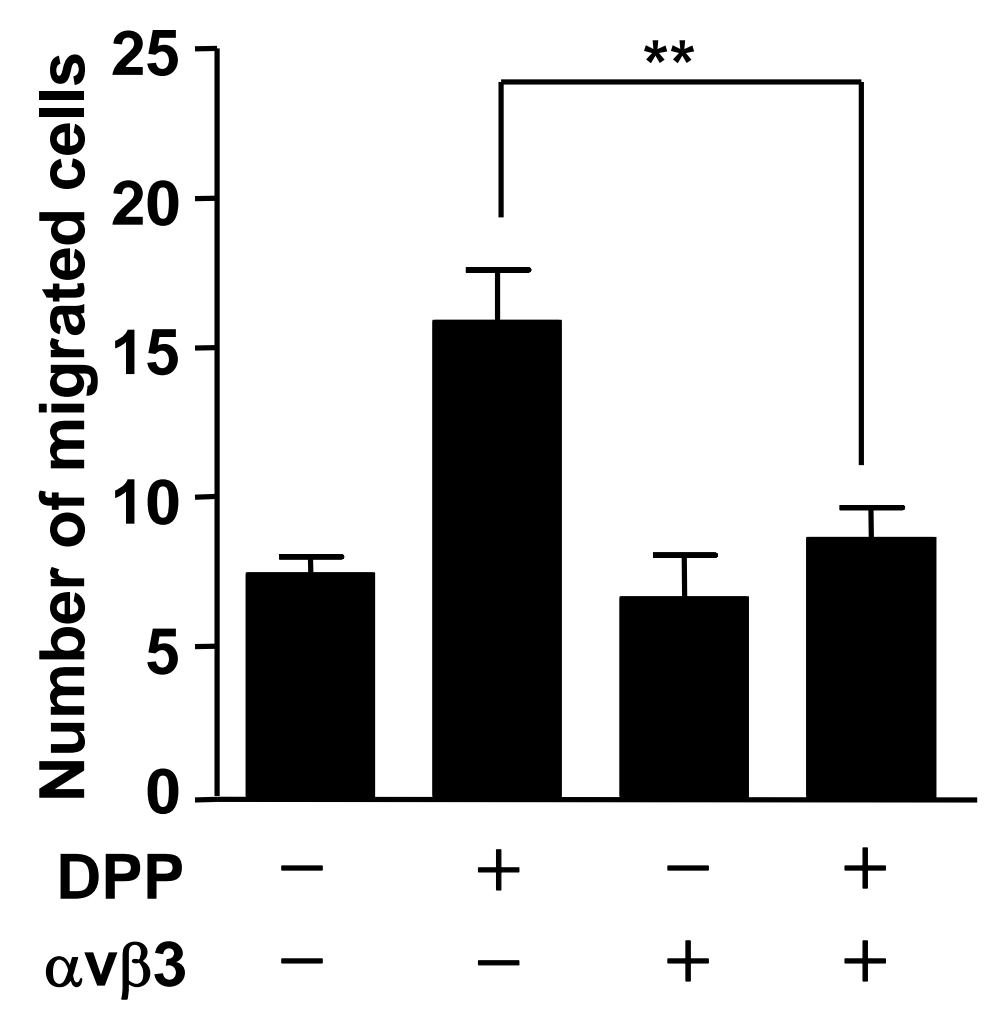

(B)

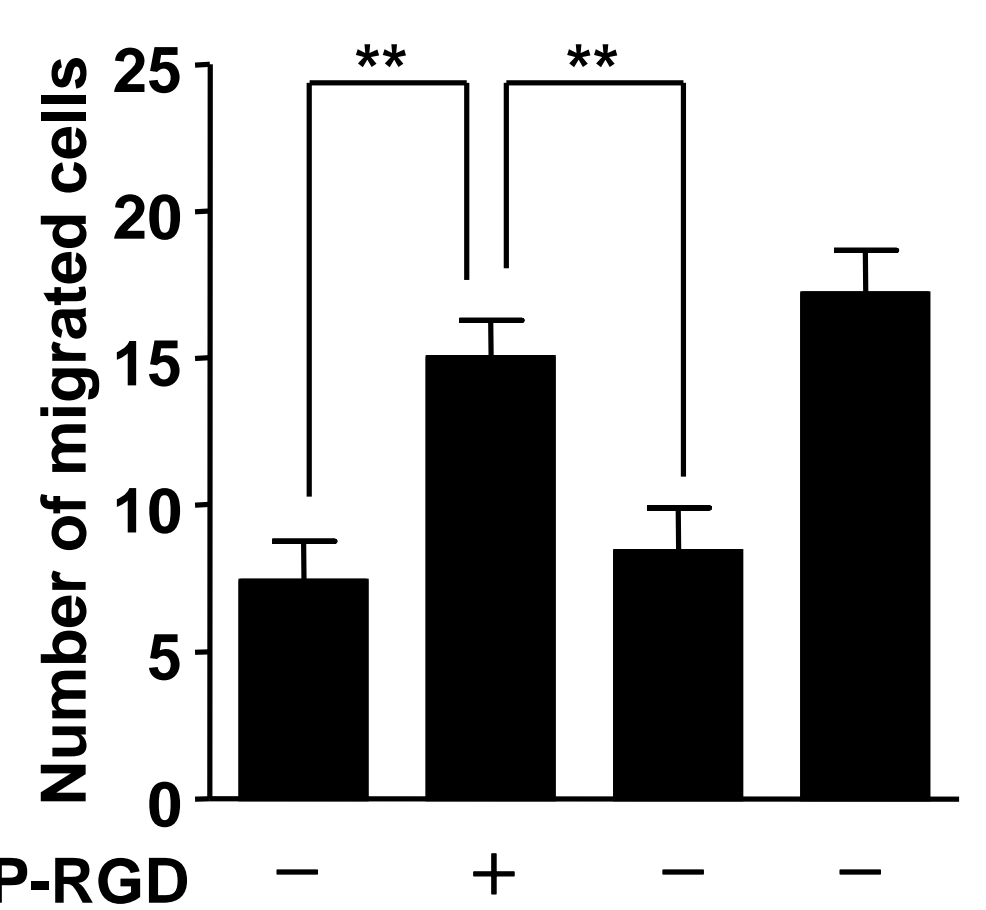

DPP-RAD - $\quad-\quad+\quad-$

Fibronectin - $\quad-\quad-\quad+$ 